\title{
MINING AND METALLURGICAL ACTIVITIES IN N IBERIA AND THEIR LINK TO FOREST EVOLUTION USING ENVIRONMENTAL AR- CHIVES (CENTURIES AD V TO XI)
}

\author{
NOEMÍ SILVA-SÁNCHEZ ${ }^{(1)}$
}

\begin{abstract}
:
Research on palaeoenvironmental archives has challenged the widely accepted view that atmospheric metal pollution started with the Industrial Revolution, by demonstrating that it dates back to the Bronze Age when mining and metallurgical activities spread. These activities and the exploitation of natural resources for metal extraction and smelting involved intense transformation of the landscape from the Iron Age onwards, with forest decline, among others, one of the most common. This paper examines the methodology used for the detection of past atmospheric metal pollution and other environmental impacts associated with mining and metallurgy and reviews the research performed in this field in North Iberia, with special attention to centuries AD V-XI
\end{abstract}

Keywords: mining, metallurgy, atmospheric metal pollution, North Iberia, impacts on vegetation

Resumen:

\begin{abstract}
Minería y metalurgia en el Norte de la Península Ibérica y su relación con la evolución del bosque a partir de archivos ambientales (Siglos V-XI)

La investigación paleoambiental realizada en las últimas décadas en archivos ambientales ha demostrado que, a pesar de hasta hace poco se creía que la contaminación atmosférica metálica habría comenzado con la revolución industrial, las evidencias más antiguas se remontan ya a las primeras sociedades metalúrgicas. Las actividades mineras y metalúrgicas así como la explotación de los recursos naturales para la extracción y procesado de los metales supuso intensas modificaciones del paisaje, siendo la tala de bosques, entre otras, una de las más habituales. En este trabajo se examina la metodología empleada para el estudio de la evolución de la contaminación atmosférica metálica y otros impactos asociados con la minería y la metalurgia y se revisa la investigación realizada en este campo en el Norte de la Península Ibérica, con especial atención al periodo comprendido entre los siglos V-XI AD.
\end{abstract}

Palabras clave: minería, metalurgia, contaminación atmosférica metálica, Norte ibérico, impactos en la vegetación

\section{INTRODUCTION: THE STUDY OF PAST ATMOSPHERIC METAL POLLUTION AND ITS IMPACTS}

For a long time atmospheric metal pollution was considered to have started with the onset of the Industrial Revolution, forced by increased population and an unprecedented technological and economic development. This has been commonly accepted despite archaeological evidence that human activities, like mining and metallurgy, already caused atmospheric pollution several millennia ago. Some of the first studies of palaeopollution were published in the $1980 \mathrm{~s}$ (NRIAGU 1980; 1983). Later research on palaeoenvironmental archives demonstrated that the evidence of atmospheric metal pollution dates back indeed to metal culture age (e.g. MARTínEZ CORTIZAS et al. 1997; LEBLANC 2000; MigHALL et al. 2002a; PONTEVEDRA-POMBAL et al. 2013). Minero-metallurgical activities produced intense environmental changes since ancient times. Some of the most well studied European prehistorical mining centres are found in mid Wales, UK, where the Early Mines Research Group did an exhaustive study of the environmental impact associated with Early Bronze Age copper mining (e.g. CREW \& CREW 1990; Mighall et al. 1993; CRADDOCK 1995; TIMBERLAKE 2001). While the first evidence of environmental impact associated to mining goes back to the Bronze Age, the Roman period can be considered a key point when evaluating the environmental impact associated with mining (e.g. LEWIS \& JONES 1970; DURALI-MUELLER et al. 2007; MARTíNEZ CORTIZAS et al. 2013; LÓPEZMERINO et al. 2014; PY et al. 2014).

One of the most emblematic examples of the changes that happened during this period can be found in Las Médulas (León, Spain), where, interestingly, landscape forms created by mining operations are now protected by different legal

${ }^{(1)}$ Edafología y Química Agrícola, Fac. Biología, Campus Sur, Universidad de Santiago de Compostela, Rúa Lope Gómez de Marzoa s/n. E-15782, Spain. noemi.silva.sanchez@usc.es; n.o.e.s@hotmail.com 
figures: Spanish Heritage Cultural Interest Site (1996), UNESCO World Heritage Site (1997) and Spanish Heritage Natural Monument (2002). Unfortunately, despite the existence of such remarkable examples, the interpretation of mining landscapes is, frequently, complex. Based solely on the evidence from archaeological excavation it is difficult to ascertain when metallurgical activity actually commenced, its duration and whether it took place continuously or in phases. A furnace, for example, can be archeomagnetically or radiocarbon dated, but this date only provides an indication of its construction age and/or when it was last used (MigHALL et al. 2006b). The great majority of old metal mines are multi-period. Some of them have been exploited repeatedly over hundreds/thousands of years. Moreover, later activity and a lack of dateable artefacts can make it difficult to build an accurate chronological sequence of events using archaeological material alone (OREJAS 1996; Mighall et al. 2006b). Palaeoenvironmental studies on natural archives can produce indirect evidence that may provide a solution for some of these issues. The study of certain indicators -both abiotic: elemental composition, physical-chemical properties, etc., and biotic: pollen, spores, etc- that are deposited in environmental archives through time, combined with absolute dating methods, may be of help to reconstruct the intensity and the chronology of the environmental transformations that took place in a given landscape. Ice cores (e.g. MUROZUMI et al. 1969; HONG et al. 1994; ROSMAN et al. 1994, 1998), lake sediments (e.g. FARMER et al. 1996, 1997; RENBERG et al. 2000, 2002; BINDLER et al. 2001; BRÄNNVALL et al. 2001; OUTRIDGE et al. 2002; YANG \& Rose 2005; MichelutTi et al. 2009) and peatlands (e.g. SHOTYK 1998, 2002; WEISS et al. 1999; SHOTYK et al. 2001; MARTÍNEZ CORTIZAS et al. 2002b; Mighall et al. 2002b, 2006b, 2009, 2014; DE VleESCHOUWER et al. 2010; KÜTTNER et al. 2014) constitute the environmental archives more often used for atmospheric metal pollution. However, in North Iberia, the scarcity of permanent ice sheets makes of peatlands (e.g. MARTíNEZ CORTIZAS et al. 1997, 2002a, 2002b, 2013; KYLANDER et al. 2005; PONTEVEDRA-POMBAL et al. 2013) and to a lesser extent lakes (e.g. CAMARERO et al. 1998; LEBLANC, 2000; GARCÍA-ALIX et al. 2013) the most used environmental archives. With the study of these archives at an appropriate sampling resolution, phases of mining and metallurgy can be identified and dated, thus providing valuable information about the duration and chronology of these activities, specially when archaeological information is scarce or confused (MIGHALL et al. 2006b). In fact, one of the main advantages of the application of palaeoenvironmental research to the detection and quantification of mining and metallurgical activities is that, contrary to other disciplines, it offers a nearly continuous record of environmental change. Multiproxy approaches have been widely used to detect the impacts linked to the development of minero-metallurgical activities (e.g. MONNA et al., 2004b; MARTínEZ CORTIZAS et al. 2005; JOUFFROY-BAPICOT et al. 2006; Mighall et al. 1997; 2006b, 2013; BREITENLECHNER et al. 2010; LÓPEZ-MERINO et al. 2011; PONTEVEDRA-POMBAL et al. 2013).

This paper reviews the methodology that has been developed for the detection of past atmospheric metal pollution and the impacts associated with past mining and metallurgy. I also review the research conducted in this field in North Iberia, a key region for studying past metal pollution due the wealth of mineral deposits, the multi-period history of the industry and the variation in the intensity of mining exploitation through time. Although focused on the period from $\mathrm{AD} \mathrm{V}$ to $\mathrm{XI}$, the information on previous periods also warrants comment in order to contextualize this phase in a wider framework. The geographic location of relevant zones in the study of palaoepollution in the North of the Iberian Peninsula is shown in Figure 1.

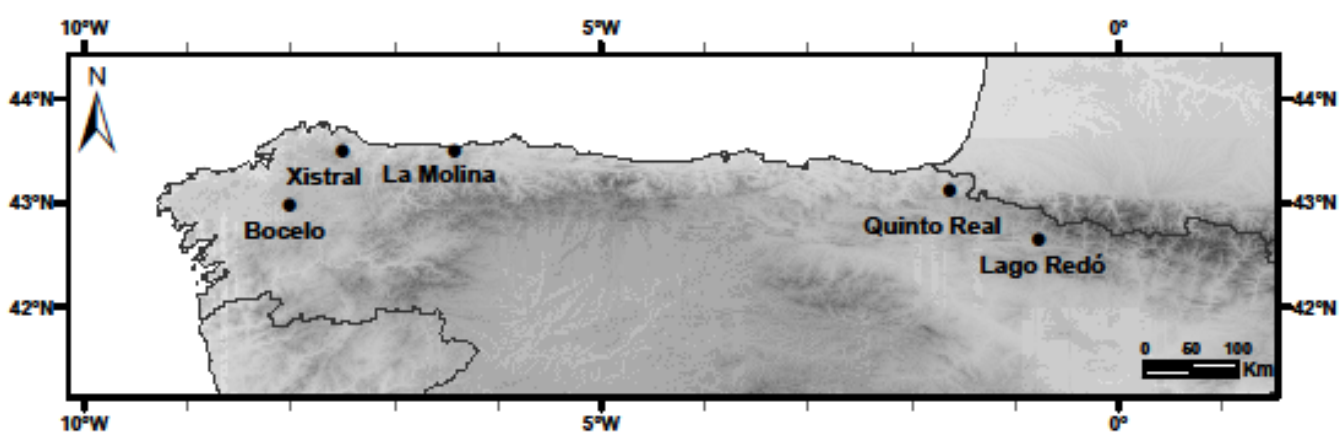

Fig. 1. Location of the studied areas most cited in the text

Fig. 1. Localización de las áreas de estudio más citadas en el texto 


\section{RECONSTRUCTION OF ATMOSPHERIC METAL POLLUTION: GEOCHEMICAL PROXIES}

Until the exploitation of fossil fuels as a main source of metals to the atmosphere, anthropogenic metal emissions were mainly related to mining and metallurgical activities. In fact, the reconstruction of the intensity of this type of activity is based on the application of geochemical methods for the quantification of palaeopollution. Despite numerous factors can affect the dispersion of gaseous and particulate pollutants from their emission sources (e.g. DAVIES 1983; MACKLIN 1992), peatlands near minero-metallurgical production centres, capture pollutants on to their surface, thereby giving an accurate chronological record of its activity (Mighall et al. 2006b).

Among metals, lead is the most widely used for the reconstruction of atmospheric pollution history, as it has been one of the first metals for which the lack of postdepositional remobilization was demonstrated (e.g. SHOTYK et al. 1996; MACKENZIE et al. 1997) as well as one of the most common pollutants from ancient times to recent periods (KYLANDER et al. 2005). More recently, the utility of $\mathrm{Hg}, \mathrm{Cu}, \mathrm{Ni}$ or $\mathrm{Cd}$ has been also demonstrated (e.g. Mighall et al. 2002a; YANG \& Rose, 2005; PONTEVEDRA-POMBAL et al. 2013; KÜTTNER et al. 2014).

Metals content in peat, as well as its concentration in the atmosphere (from which they are deposited), also depends on matrix properties (like the type of minerals present or the proportion of mineral matter). Thus, the metals can have both anthropogenic and natural sources. Because of that, metal concentrations are not reliable enough to reconstruct anthropogenic vs. natural sources of the metals in the atmosphere. Other approaches are needed. One solution proposed to solve this problem is the calculation of enrichment factors (EF) (e.g. SHотук, 1996). An enrichment factor is a normalized ratio between a metal concentration and the concentration of a conservative element in a sample with regard the same ratio in a reference material usually either the Earth crust, a given rock type, soils or, as desirable and if possible, prepollution samples of the environmental archive studied. Thus, an EF provides a way to evaluate the magnitude of the atmospheric fluxes exceeding the natural background in an area. The higher the pollution levels the higher the EF will be. EF can be very useful for the reconstruction of relative variations through time but they also present some limitations. For example, Reimann \& De Caritat (2000) strongly criticized the use of Earth crust values in EFs calculations and they suggest the need to use statistically significant environmental data. One problem is that the concentration of conservative elements used for the normalisation of EF can show regional variations due to differences in min- eralogical composition (WEISS et al. 2002) limiting the comparison of pollution levels in different environments. Even at a local scale, differences due to physical fractionation during wind transport (MARTÍNEZ CORTIZAS et al. 2002a) can affect the EF. Because of these limitations, some authors suggest that multivariate statistic solutions are desirable to separate natural and pollution signals (e.g. MARTínez CORTIZAS et al. 2013).

The increase in research on lead isotopes in natural archives in recent years (e.g. KOMÁREK et al. 2008 and references there in) indicates that they have also become important for the evaluation of the enrichment and the sources of atmospheric metal pollution (e.g. BINDLER et al. 2001; SHOTYK et al. 2003; KYLANDER et al. 2005, 2010). Lead isotopic signatures are commonly expressed as ratios between two isotopes. The most widely used is the ${ }^{206} \mathrm{~Pb} /{ }^{207} \mathrm{~Pb}$ ratio, which tends towards lower values with increasing pollution. When lead sources are known and the isotopic signatures of materials are properly characterised, it is possible to calculate the relative contribution of each source applying simple mixing models (RENBERG et al. 2002). Despite their limitations, EF are still used and often compared with other pollution indicators such as lead isotopes (e.g. WEISS et al. 1999). Thus, metal concentrations, enrichment factors and isotopic ratios, with few local peculiarities, should reflect very similar patterns.

\section{RECONSTRUCTION OF FOREST EVOLUTION: PALYNOLOGICAL PROXIES}

Atmospheric metal pollution is not the only detectable environmental impact of mining and metallurgy. Besides the large transformations of the landscape linked to the construction of extraction facilities, that in some cases even resulted in creation of new habitats that still exist today (like lakes or wetlands) (e.g. LÓPEZ-MERINO et al. 2011), the exploitation of natural resources for the extraction and further processing of metals, also in many cases led to intense environmental modifications. For example, the use of wood as raw material in the construction of extractive facilities and as fuel for smelting may have caused intense reductions in forest cover (e.g. MONNA et al. 2004b; JOUFFROY-BAPICOT et al. 2006; MIGHALL et al. 2006b, 2013; BREITENLECHNER et al. 2010; PONTEVEDRAPOMBAL et al. 2013). Although there is also plenty of evidence of woodland management (vs. clearance) to produce firewood or in order to ensure charcoal supply (e.g. MCKEOWN 1994; MighaLL et al. 2000; SZABÓ et al. 2015), since charcoal was needed by metalworkers as fuel to ore smelting.

Pollen and spores preserved in environmental archives are among the earliest environmental proxies studied (e.g. IVERSEN 1941). The reconstruction of past vegetation is a useful tool for studying the use past human populations made of its environment in general and of vegetation in 
particular. Pollen analysis is based in the fact that pollen and spores preserved in environmental archives can be taxonomically identified and quantified. This, combined with an accurate chronological control, allows the reconstruction of past changes in vegetation. Initially, palaeopalynological studies mainly focused on pollen and moss and ferns spores, thus regional signals prevailing over local signals. In the last decades however, palaeopalynology has broaden its range of application as many other "non pollen palynomorphs" (NPP), mainly produced by fungi and algae, have been included in pollen studies. NPP, due to their limited dispersal, give valuable information at a local scale (e.g. VAN GEEL et al. 1989; VAN GEEL 2001). Among them there are proxies for anthropogenic pressure on landscapes -grazing, fire incidence or soil erosion- (e.g. ANDERSON et al. 1984; RIERA et al. 2006; LÓPEZ-MERINO et al. 2009; CUGNY et al. 2010; EJARQUE et al. 2011; ABEL-SCHAAD \& LÓPEZSÁEZ 2012; GILL et al. 2013) and proxies for environmental conditions such as hydrological changes or the erosion of catchment soils (e.g. MigHALL et al. 2006a; MEDEANIC \& SILVA 2010).

Despite timber being of great importance for the development of mining and metallurgical activities, until recent times, the role of mining and metallurgy in forest evolution has been an aspect almost neglected, at the expense of other forcings in cultural landscapes such as agriculture and grazing (CHAMBERS 1993). One of the reasons of this bias is possibly related with methodological reasons. Palynological proxies provide information about both forest evolution and agriculture (cereal presence) and grazing activities (anthropozoogenous and nitrophilous taxa as well as coprophilous fungi), whilst the detection of mining and metallurgical activities needs geochemical approaches and/or the presence of well studied and contextualised archaeological sites. Thus, multiproxy approaches are needed for detecting this type of synergies. Something that, even nowadays, is relatively uncommon. Another aspect behind this bias could be the fact that agriculture and mining/metallurgy coexist making very difficult to disentangle the effects caused by each activity.

Forest clearance linked to timber extraction for minero-metallurgy development would have occurred since prehistory (e.g. MighaLl \& CHAMBERS 1993, 1997; MONNA et al. 2004a, 2004b). It is usually reflected in palynological diagrams by a decrease in total arboreal pollen, although sometimes selective clearance of one or two taxa might not affect the total arboreal signal.

Thus multiproxy approaches combining palaeopollution reconstruction and other geochemical methods with palaeopalynology allow for the evaluation of possible synchronicities between minero-metallurgical activities and other aspects of environmental change such as forest clearance, soil erosion or hydrological changes at a basin scale (e.g. Mighall \& Chambers 1993; MartíNeZ CoRTIZAS et al. 2005; MIGHALL et al. 2006b, 2013; LÓPEZ-MERINO et al. 2011, 2014; PONTEVEDRAPOMBAL et al. 2013).

\section{EVOLUTION OF ATMOSPHERIC METAL POLLUTION IN NORTH IBERIA}

\subsection{First evidence of atmospheric metal pollution}

Until recently, the oldest evidence of metal pollution in Iberia dates back to about 4500 years ago. It was detected in estuarine sediments from the Tinto River, where a sharp increase in $\mathrm{Pb}, \mathrm{As}$ and $\mathrm{Cu}$ concentrations was recorded (LEBLANC, 2000). This was attested by the presence of small slags in the sediment that proved the development of metallurgical activities at a local scale dating to 2530 BC. More recently, Galop et al. (2001) found a geochemical anomaly (enrichment in $\mathrm{Pb}$ and decrease in the ratio ${ }^{206} \mathrm{~Pb} /{ }^{207} \mathrm{~Pb}$ ratio) in a section with an age earlier than $2600 \mathrm{BC}$ of peat core from the Basque country. Moreover, ongoing research in La Molina mire (Asturias) suggests that the first evidence of atmospheric metal pollution in North Iberia may even be traced back to the Early Bronze Age, around 5000 years ago (Martínez Cortizas, 2014: personal communication). This diversity of ages in the onset of atmospheric metal pollution suggests that the timing of mining and metallurgy was locally variable and the impact was spatially restricted. In Galicia, the oldest evidence of palaeopollution dates back to about 3000-3500 years and has been found in peatlands from the Xistral Mountains. Martínez Cortizas et al. (1997), based on the study of enrichment factors in a peat core, detected the first evidence of atmospheric pollution in layers with an age of 930 BC. Subsequently, the study of the $\mathrm{Pb}$ isotopic composition revealed that $\mathrm{Pb}$ atmospheric pollution would have indeed begun by $1260 \mathrm{BC}$, although it was not until $1000 \mathrm{BC}$ when it dominated ( $>50 \%) \mathrm{Pb}$ deposition (KYLANDER et al. 2005). More recent studies in other metals in peatlands of the Xistral mountains pushed back the onset of atmospheric metal pollution to $1400 \mathrm{BC}$, when the first $\mathrm{Ni}$ enrichments were recorded (PONTEVEDRA-POMBAL et al. 2013). Although Garcia-Alíx et al. (2013) recommend to take the date of this proposed anthropogenic "nickel event" with caution due to Ni being a redox -sensitive element.

\subsection{Atmospheric metal pollution during the Roman Period: pre-industrial climax}

North Iberia becomes one of the most important mining centres during the Roman Period. Iberian mines generated $60 \%$ of the European lead production (NRIAGU 1983) and in Northwest Iberia around 500 mines were exploited. Mining activity mainly focused on gold, but also on lead, zinc, cooper, silver, iron and tin. The timing of this exploita- 
tion comprises the first two centuries $\mathrm{AD}$ and its start and end are connected to the operation of the Roman monetary system based on gold-silver bimetallism (CAAMAÑO 2007). During this period, both at a European and Iberian level, atmospheric metal pollution produced by minero-metallurgical activities was widespread and increased in intensity. In peat cores records from North Iberia an increase in atmospheric metal pollution is detected both in Galicia - Xistral mountains (Figure 2A; MARTínEZ CORTIZAS et al. 1997, 2002a; KYLANDER et al. 2005) and Bocelo mountains (Figure 2B; SILVA SÁNCHEZ 2010) -, in the Basque country - Quinto Real (GALOP et al. 2001, 2002; MONNA et al. 2004a) - and in Asturias - Alto de la Espina range (Figure 2C; MARTínez CORTIZAS et al. 2013). Polymetallic studies in the Xistral mountains also show increases in the enrichment factors of nickel, arsenic and cadmium (MARTíNEZ CORTIZAS et al. 1997; PONTEVEDRA-POMBAL et al. 2013). While most of the records show increased pollution from $200 \mathrm{BC}$ to $\mathrm{AD} 400$, maximum values, especially in the northwest, occurred in centuries AD I-II. A good example is the Alto de la Espina record, which has an extraordinary chronological resolution for the Roman period and in which pollution lead increases from 20 to $88 \%$ over these two centuries (MARTíNEZ CORTIZAS et al. 2013). The close proximity of "Alto de la Espina" to well known gold mining centres may account for this intense pollution. The collapse of the Roman Empire signalled a general decline in atmospheric metal pollution, though timing of the decline is slightly different in western and eastern North Iberia, indicating local differences in the processes of abandonment of mining activities.

\subsection{Atmospheric metal pollution in V-XI cen- turies AD}

After the fall of the Roman Empire metal pollution levels in the atmosphere drastically decreased, occurring earlier in Galician ( 450 AD) than in Asturian and the Basque records ( $\sim 550 \mathrm{AD}$; Figure 2$)$. Disarticulation of Roman power structures greatly affected mining intensity, representing a sharp break with the precedent model of exploitation of natural resources. However, the intensity of the process was not the same throughout North Iberia. For example, in Quinto Real (Basque country) (GALOP et al. 2001, 2002; MONNA et al. 2004a) the collapse in minero-metallurgical production happened more gradually than in the other North Iberian sites. This is probably because Romanization was also less intense in this region than at other sites in North Iberia (MONNA et al. 2004a).

With the onset of the Germanic Period, around AD 550-600, atmospheric pollution signals become again relevant, indicating a recovery of minerometallurgical activities, at least in Galicia, while in Asturias and in the Basque Country there is still no sign of a resumption (Figure 2). In Xistral (Galicia; Figure 2A), despite lead concentrations in the peat abruptly decrease from Roman times and slightly increase around $\mathrm{AD} 1050$, with the isotopic composition more sensitive to low intensity pollution (MUNKSGAARD \& PARRY, 1998). Both signals indicate a gradual increase in anthropogenic emissions to the atmosphere between $\mathrm{AD} 500$ and 1200, with brief occasional increases centred at AD 675 and 1050. In Bocelo (Galicia; Figure 2B) however, pollution lead increased as early as AD 620 and more intensely between AD 900 and 1240, peaking around AD 1060. This trend suggests that in Medieval Galicia mining and metallurgy would have peaked in the transition between AD VI-VII and X-XI centuries. Although lead enrichment factors show a trend to decreasing values from $\mathrm{AD} 400$, the isotopic signal indicates a continuous increase in metal pollution from AD 550 to 1110 in Quinto Real peatland (Basque Country) (GAlOP et al. 2001, 2002; MonNA et al. 2004a); while in La Molina mire (Asturias; Figure 2C) the recovery of minero-metallurgical activities did not take place until AD 610. Here the isotopic composition points to an increase in metal pollution between AD 610 and 980 (with a maximum at AD 750) and between $\mathrm{AD} 1110$ and 1270 (with a maximum at $\mathrm{AD}$ 1190). Comparing Medieval and Roman times, it is noteworthy that in Bocelo the intensity of medieval minero-metallurgical activities in some phases would have been similar, or even higher (towards AD 1000), to that of Roman times. In La Molina, Xistral and Quinto Real however, medieval atmospheric pollution signals seem to have been of lower intensity than the Roman ones. According to this, minerometallurgical activities during the Middle Ages were probably less intense than in Roman times. Although it cannot be ruled out that the new mining and metallurgy production centres would have been further away from the mires or that technical improvements in extraction resulted in lower metal emissions to the atmosphere, causing lower metal deposition.

Atmospheric pollution levels in North Iberia indicate that despite archaeological evidence of medieval mining being much lower than in Roman times, mining/metallurgy could have been, at least in some areas, such as Bocelo, an important economic activity. Differences in the signal recorded by the environmental archives considered here indicate that the local history may have played a very important role in the evolution of metal pollution. In fact, and far from the norm, in some isolated places the first evidence of exploitation of local mines occurred in Middle Ages. This is suggested, for example, by a research performed on lake sediments from Redó Lake (Pirineos; CAMARERO et al. 1998). Here, lead concentrations and lead isotopic composition showed little variation in sediments layers of Roman age. Changes in these indicators from AD 470 point towards the initiation of extractive activities at a local scale that would have been in operation until AD 1100, with a maximum around AD 660. 


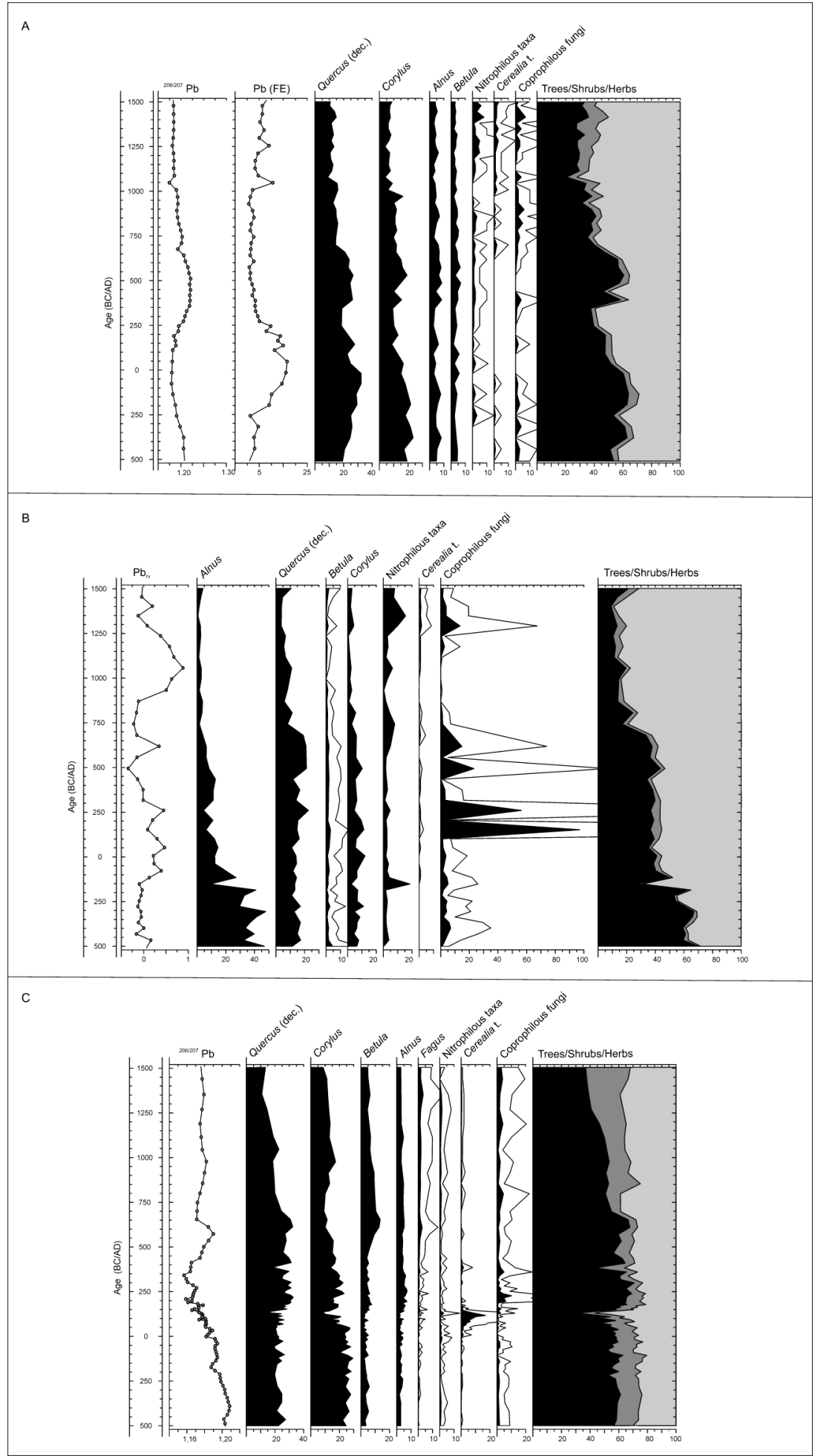

Fig. 2. Atmospheric metal pollution indicators and selected palynological taxa (in percentage) from: A) Penido Vello bog (PVO core), Xistral mountains, Galicia (MARTÍNEZ CORTIZAS et al. 1997, 2002a; KYLANDER et al. 2005; MigHALl et al. 2006a); B) Cruz do Bocelo mire (PPB core), Bocelo mountains, Galicia (SILVA-SÁNCHEZ 2010; SILVA-SÁnCHEZ et al. 2014) and C) La Molina mire (TAE core), Alto de la Espina Range, Asturias (LóPEZ-MERINO et al. 2011, 2014; MARTíNEZ CORTIZAS et al. 2013). Quercus (dec.): oak; Corylus: hazel; Betula: birch; Alnus: alder; Fagus: beech.

Fig. 2. Indicadores de contaminación metálica atmosférica y porcentajes de indicadores palinológicos seleccionados de: A) turbera e Penido Vello (testigo PVO), Montañas del Xistral, Galicia (MARTínez CoRTIZAS et al. 1997, 2002a; KYLANDER et al. 2005; Mighall et al. 2006a); B) turbera de Cruz do Bocelo (testigo PPB), Montes del Bocelo, Galicia (Silva-SÁnCHEZ 2010; SILVA-Ś́NCHEZ et al. 2014) y C) turbera de La Molina mire (testigo TAE), Sierra del Alto de la Espina, Asturias (LÓPEZ-MERINO et al., 2011, 2014; MARTíneZ CORTIZAS et al. 2013). 


\section{COUPLING FOREST EVOLUTION AND OTHER IMPACTS OF MINERO-METALLURGICAL ACTIVITIES IN NORTH IBERIA}

\subsection{Changes in forest evolution linked to the first evidence of atmospheric metal pollution}

In North Iberia, several studies have reported a reduction in forest cover associated with prehistoric mining and metallurgy. Decreases in several tree taxa characteristic of the mixed deciduous forest occurred at the same time that the first evidence of metal working was being recorded in natural archives. As reported by PONTEVEDRAPOMBAL et al. (2013), after the Neolithic period and the subsequent recovery of the forest, a new deforestation phase, beginning at ca. $3500 \mathrm{cal} \mathrm{BP}$ (Bronze Age), was synchronous with the first evidence of metal pollution in the region, which was recorded locally by an increase in nickel. In the palynological diagram (MIGHALL et al. 2006a) it can be seen that this corresponds to a decrease in alder, oak and hazel. In Quinto Real (GALOP et al. 2001, 2002; MonNA et al. 2004a) Middle Bronze Age to Iron Age phases of atmospheric metal pollution occur simultaneously with the loss of oak and hazel. Since indicators of agropastoral and slash-and-burn activities also decrease or are simply absent, forest decline was possibly linked to mining/metallurgical activities.

\subsection{Changes in forest evolution linked to atmospheric metal pollution during the Roman Period}

Scale and duration of minero-metallurgical activities largely influenced the magnitude of the environmental impact that these activities had on vegetation and other landscape features (MIGHALL et al. 2006b). The aggressive methods of mining extraction during Roman times caused a diversification of environmental impacts. The most evident and persistent over time and, thus, the most well known is the geomorphologic transformations derived from the large amounts of material removed by hydraulic extraction methods (ruina montium). Examples of this type of transformation can be found in Las Médulas (León) and in Monte Furado (Lugo) (LEWIS \& JONES 1970; SÁNCHEZPALENCIA et al. 2009).

But mining production in Roman times also caused perturbations that either have left no tangible mark on the present day landscapes or are not so obvious to the naked eye. This is the case of environmental changes that took place in $\mathrm{La}$ Molina mire in Asturias. A place that has been declared as Site of Community Interest (Natura 2000) and that would not appear to have had anything to do with mining. Nearby La Molina, in the Narcea-Pigüeña area, a complex hydraulic system to funnel water from the mountains (FERNÁNDEZ MIER 1999) was found. Hydraulic systems consist- ing in canals (corrugi) and water reservoirs (piscinae o stagna) were common in Roman mines for carrying out mining extraction. From the geochemical and palynological study of La Molina mire, López-Merino et al. (2011) concluded that between the AD 20 and 140 the peatland would have been used as a piscinae. Taxa indicative of riparian habitats were detected and the content of organic matter increased. The use of the peatland as a water deposit caused a no-return point in the hydrological conditions of the wetland, leading to a change from minerotropic to ombrotropic status. Curiously, this characteristic, ultimately proved to have had an anthropogenic origin, and survives until today, has been one of the key properties taken into consideration to declare the mire as Site of Community Interest in the Natura 2000 network. The use of La Molina mire as piscinae also produced other changes in the landscape. Although metal extraction and processing is normally linked with forest decline, in the case of La Molina arboreal pollen percentages increased (Figure 2C; LÓPEZ-MERINO et al. 2014). Analyzing the pollen record in detail it turned out that this was due to relative increases in oak, birch, alder, ash, elm and maple. Damper conditions linked to the presence of shallow open water would have led to the spread of these taxa. Other trees, such as hazel and, in some particular phases, even oak decreased in abundance coinciding with minero-metallurgical production peaks. However, as an increase in agriculture and grazing indicators is recorded at the same time, it is difficult to attribute the observed changes to a single cause. So, a combination of factors seems to be the most probable scenario.

In other areas of North Iberia, Roman mining may have caused a decrease in most arboreal taxa. In Bocelo (Galicia; Figure 2B), the increase in atmospheric metal pollution was accompanied by a sharp decrease in total arboreal pollen, mainly due to the decrease of alder and to a lesser extent hazel and oak. But, synchronous increases in cereal pollen suggest agriculture could also account for the forest decline. Anyway, the abrupt and intense deforestation that took place in these mountains during the Roman Period triggered a series of cascading environmental changes (SILVA-SÁNCHEZ et al. 2014). Increased mineral matter inputs into the mire and the presence of the NPP Glomus (HdV207) indicate intense soil erosion due to forest clearance. At the same time, larger abundance in NPP HdV-18 points to an increase in the watertable level of the mire, which was probably related with a loss of water retention capacity of the soils of the catchment as a result of forest loss. In the Xistral mountains (Galicia; Figure 2A) and in Quinto Real peatland (Basque country; GALOP et al. 2001, 2002; MONNA et al. 2004a) the increase in metal pollution is coeval with decreases in total arboreal pollen characterised by a decline in oak, 
hazel and alder in the first instance and subsequently oak and hazel. No substantial increases in farming indicators occurred, suggesting a much more clear relationship between forest changes and minero-metallurgical activities. Moreover, anthracological research performed in Quinto Real area indicates that oak was used for coal production during the Roman Period (GALOP et al. 2002).

\subsection{Changes in forest evolution linked to at- mospheric metal pollution between centu- ries AD V-XI}

Collapse of minero-metallurgical activities after the Roman Period generally led to a decrease in the anthropogenic pressure on the forests of North Iberia and in some cases their recovery to a nearly pre-Roman situation.

In Galicia, forest clearance associated with minero-metallurgical and farming activities between centuries $\mathrm{AD} \mathrm{V}$ and IX led to a permanent decrease of mixed woodland. In Xistral (Fig. 2A) the lead isotopic signal showed a relative maximum in atmospheric metal pollution towards $\mathrm{AD}$ 675. At this moment, coinciding with the rise of the mining and metallurgical activities, and evidence of the intensification of farming, the percentage of total arboreal pollen decreases sharply due to declining oak, alder and hazel. Although alder partially recovered after that, the decrease in oak and hazel was permanent and the pre-Germanic level of forest cover was never reached again. Forest retreat in the Xistral Mountains led to a much more open landscape dominated by heath scrub. This landscape that is still dominant nowadays and declared as Site of Community Importance in Natura 2000 (due to the presence of habitats 4020 "Temperate Atlantic wet heaths of Erica ciliaris and Erica tetralix" and 4030 "European dry heaths", among other). In view of the evidence, this landscape could have been consolidated phytosociologically in the Germanic period due to the action of human activity. In Bocelo (Fig. 2B), the decrease of alder and hazel began by AD 450-500, probably due to an expansion of agricultural land and grazing at a local scale. Although, towards AD 620 , Germanic lead pollution was at its highest level, so the influence of mining and metallurgy on the demise of the forest cannot be totally ruled out. Between AD 680 and 805, in a moment when metal atmospheric pollution was minimal, both cereal and nitrophilous taxa increased while oak, which until that moment was the most abundant tree taxa due to the selective pressure exerted over alder and hazel, sharply decreased. In Bocelo, forest clearance also promoted more open landscapes, but in this case dominated by herbaceous formations instead of heather shrubs.

Between the centuries AD X and XIII AD a new regressive event in the history of the Galician forest took place. In Xistral, the geochemical stud- ies indicate an increase in atmospheric metal pollution towards AD 1050 in association with considerable decrease of oak, hazel and to a lesser extent alder. But, again, the presence of cereal pollen grains and coprophilous fungi does not enable to rule out other agricultural causes. In Bocelo, maximum medieval pollution levels had a longer chronological distribution (AD 900-1240) and magnitude. However, the decrease in the mixed deciduous forest seems to have been more related with variations in cereal pollen and coprophilous NPP than with mining and metallurgy.

At La Molina mire (Fig. 2C), mining and metallurgy expansion between $\mathrm{AD} 610$ and 980 and AD 1110 and 1270 coincided with both decreases in oak and hazel. During these periods cereal percentages are maintained, and although grazing indicators increased punctually, the good agreement between the trend in atmospheric metal pollution and those tree taxa, allows the attribution of most of the woodland change to mining and metallurgical activities. Like elsewhere in North Iberia, the permanent decline in deciduous forest, dated to the late AD VII century, allowed heathland to form. In Quinto Real (GALOP et al. 2001, 2002; MONNA et al. 2004a) however, there is no a clear link between oak, hazel and beech decreases and metal pollution during AD 550-1100, as Cerealia showed a large expansion over the period. Pollen records of La Molina and Quinto Real show a peculiarity not seen at their Galician counterparts. Since the change of era, beech became increasingly important in mixed deciduous forest. In La Molina mire beech presence did not prevent the collapse of the forest during the Germanic Period, but in Quinto Real the larger abundance of beech allowed the deciduous forest to endure into the $\mathrm{AD}$ XVI century - despite that after AD VII most of the other tree taxa showed very low values.

\section{CONCLUSIONS}

The study of metal accumulation in peatlands allows insights into the development of mining and metallurgy activities over time, at local and regional scales. The Roman period led to an unprecedented increase in the development of mining and metallurgy in North Iberia, especially in AD I-II centuries. These activities were closely related with the power structures of the Roman Empire so that its fall, although with different chronologies for East and West North Iberia, led to a collapse in mining and metallurgy. In Galicia, the decline in atmospheric metal pollution indicators occurred around $\mathrm{AD}$ 450, while in Asturias and in the Basque country it was delayed by a century. Between AD V and XI centuries, in the Middle Ages, atmospheric metal pollution rose again in North Iberia. In the Galician records maxima were detected between AD VI-VII and X-XI centuries, becoming in some areas (i.e Bocelo) of greater 
magnitude than that occurred during the Roman Period. While in Asturias, medieval phases of pollution would have been more extensive (AD VII-X and XII-XIII), but smaller in magnitude when compared to the Roman Period. In Quinto Real, the medieval phase of metal pollution was the longest (VI-XII), but also the one of lowest intensity. Despite the intense mining activity that occurred in Roman times in North Iberia, some new mines only became active in Middle Ages. For example, in sediments from lake Redó evidence of metal pollution started by AD 470 (CAMARERO et al. 1998).

Multiproxy studies combining geochemical and palynological research enable us to evaluate of the influence minero-metallurgical activities on vegetation. In regions located far away from where the minero-metallurgical activities took place, the decrease in forest cover was only recorded when metallurgical activities were at its maximum. However, it is sometimes difficult to determine the role of mining/metallurgy in forest evolution independently of other human activities (as agriculture and grazing). Although the taxa affected and the magnitude of changes differed between sites, in general the seventh century AD marked the time of permanent forest clearance in the North Iberia.

Despite the great advances made in the understanding of mining and metallurgy and its impacts in North Iberia, future multiproxy research at both palaeoenvironmental and at archaeological levels would be welcome. Special attention would be required on the identification of possible medieval mining centres.

\section{ACKNOWLEDGEMENTS}

N. Silva-Sánchez is currently supported by a FPU predoctoral grant (AP2010-3264) funded by the Spanish Government. This research was also partially developed with Xunta de Galicia funding (grants R2014/001 and GPC2014/009). I am grateful to Antonio Martínez Cortizas (University of Santiago de Compostela) for his comments on early versions of the manuscript. This paper has also been improved by suggestions from Tim Mighall (University of Aberdeen) and an anonymous reviewer.

\section{REFERENCES}

ABEl-SchaAD, D., \& LóPEZ-SÁEZ, J.A., 2012. Vegetation changes in relation to fire history and human activities at the Peña Negra mire (Bejar Range, Iberian Central Mountain System, Spain) during the past 4,000 years. Vegetation History and Archaeobotany, 22: 199-214. doi:10.1007/s00334-012-0368-9.

ANDERSON, R.S., HOMOLA, R.L., DAVIS, R.B., \& JaCOBSON, J., 1984. Fossil remains of the mycorrhizal fungal Glomus fasciculatum complex in postglacial lake sediments from Maine. Canadian Journal of Botany, 62: 2325-2328.

Bindler, R., Renberg, I., John Anderson, N., Appleby, P.G., EMTERYD, O., \& BOyle, J., 2001. Pb isotope ratios of lake sediments in West Greenland: infer- ences on pollution sources. Atmospheric Environment, 35: 4675-4685. doi:10.1016/S1352-2310(01) 00115-7.

Brännvall, M.-L., Bindler, R., Emteryd, O., \& RenBERG, I., 2001. Four thousand years of atmospheric lead pollution in northern Europe: a summary from Swedish lake sediments. Journal of Paleolimnology, 25: 421-435.

Breitenlechner, E., Hilber, M., LutZ, J., Kathrein, Y., UnterkiRChER, A., \& OEgGL, K., 2010. The impact of mining activities on the environment reflected by pollen, charcoal and geochemical analyses. Journal of Archaeological Science, 37: 14581467. doi:10.1016/j.jas.2010.01.006.

CAAMAÑO, J.M., 2007. A Galicia romana. I. A conquista romana de Galicia: ocupación do territorio e cultura material, In: Barreiro, X.R., Villares, R. (Eds.), A Gran Historia de Galicia. A Coruña,Arrecife Edicións Galegas: 175-176.

Camarero, L., Masqué, P., Devos, W., Ani-Ragolta, I, Catalan, J., Moor, H.C., Pla, S., \& SanchezCABEZA, J.A., 1998. Historical variations in lead fluxes in the Pyrenees (Northeast Spain) from a dated lake sediment core. Water, Air, and Soil Pollution, 105: 439-449.

Chambers, F.M., 1993. Climate change and human impact on the landscape. London, Chapman \& Hall.

Craddock, P.T. 1995. Early Metal mining and Production. Edinburgh, Edinburgh University Press.

CREw, P. \& CREw, S. (eds.)1990. Early Mining in the British Isles, Plas Tan y Bwlch. Occasional Paper no.1. Porthmadog: Snowdonia Press.

Cugny, C., Mazier, F., \& Galop, D., 2010. Modern and fossil non-pollen palynomorphs from the Basque mountains (western Pyrenees, France): the use of coprophilous fungi to reconstruct pastoral activity. Vegetation History and Archaeobotany, 19: 391408. doi:10.1007/s00334-010-0242-6.

DAVIES, B.E., 1983. Heavy metal contamination from base metal mining and smelting: implications for man and his environment. In: Applied Environmental Geochemistry. London,Academic Press: 425-462.

De Vleeschouwer, F., Le RouX, G., \& ShOtyK, W., 2010. Peat as an archive of atmospheric pollution and environmental change: A case study of lead in Europe. PAGES news, 18: 20-22.

Durali-Mueller, S., Brey, G.P., WigG-Wolf, D., \& LAHAYE, Y., 2007. Roman lead mining in Germany: its origin and development through time deduced from lead isotope provenance studies. Journal of Archaeological Science, 34: 1555-1567. doi:10.1016/j.jas.2006.11.009.

EJarque, A., Miras, Y., \& Riera, S., 2011. Pollen and non -pollen palynomorph indicators of vegetation and highland grazing activities obtained from modern surface and dung datasets in the eastern Pyrenees. Review of Palaeobotany and Palynology, 167: 123139. doi:10.1016/j.revpalbo.2011.08.001.

Farmer, J.G., Eades, L.J., Mackenzie, A.B., KiRIKA, A., \& BAILEY-WATTS, T.E., 1996. Stable Lead Isotope Record of Lead Pollution in Loch Lomond Sediments since 1630 A.D . Environmental science \& Technology, 30: 3080-3083. 
Farmer, J.G., MacKenzie, A.B., EAdes, L.J., KirIKA, A., \& BAILEY-WATTS, A.E., 1997. Influences on the extent and record of heavy metal pollution in sediment cores from Loch Tay in a mineralised area of Scotland. Journal of Geochemical Exploration, 58: 195-202.

FERNÁNDEZ MieR, M., 1999. Génesis del territorio en la Edad Media. Arqueología del paisaje y evolución histórica de la montaña asturiana: el valle del río Pigüeña. Ovidedo, Universidad de Oviedo.

Galop, D., Monna, F., Beyrie, A., Carozza, L., MaremBert, F., Parent, G., \& Mougin, V., 2002. Métallurgie et histoire de l'environnement au cours des cinq derniers millénaires en Pays basque nord (Vallée de Baigorri, P.-A., France): premiers résultats d'une approche interdisciplinaire. Archeologia Postmedievale, 6: 155-169.

Galop, D., Tual, M., Monna, F., Dominik, J., Beyrie, A., \& MAREMBERT, F., 2001. Cinq millénaires de métallurgie en montagne basque. Les apports d'une démarche intégrée alliant palynologie et géochimie isotopique du plomb. Sud-Ouest Européen, 11: 3-15.

GARcíA-Alix, A., JiMENEZ-EsPejo, F.J., LOZANO, J.A., JiMÉnEZ-MOREnO, G., MARTINEZ-RUIZ, F., GARCÍA SANJUÁN, L., ARANDA JiMÉNEZ, G., GARCÍA Alfonso, E., Ruiz-Puertas, G., \& Anderson, R.S., 2013. Anthropogenic impact and lead pollution throughout the Holocene in Southern Iberia. The Science of the Total Environment, 449: 451460. doi:10.1016/j.scitotenv.2013.01.081

Gill, J.L., Mclauchlan, K.K., SkibBe, A.M., Goring, S., ZIRBEL, C.R., \& WilliamS, J.W., 2013. Linking abundances of the dung fungus Sporormiella to the density of bison: implications for assessing grazing by megaherbivores in palaeorecords. Journal of Ecology, 101: 1125-1136. doi:10.1111/1365-2745.12130

Hong, S., CANDElone, J.J.-P., PATterson, C.C., Boutron, C.F., \& Civilizations, R., 1994. Greenland Ice Evidence of Hemispheric Lead Pollution Two Millennia Ago by Greek and Roman Civilizations. Science, 265: 1841-1843.

IVERSEN, J., 1941. Landnam i Danmarks stenalder, in: Pollenanalytisk Undersøgelse over Det Første Landbrugs Indvirkning Paa Vegetationsudviklingen. (Danmarks Geologiske Undersøgelse, 66, 1-68.

Jouffroy-Bapicot, I., Pulido, M., Baron, S., Galop, D., Monna, F., Lavoie, M., Ploquin, A., Petit, C., BEAUlieU, J.-L.J.-L., \& Richard, H., 2006. Environmental impact of early palaeometallurgy: pollen and geochemical analysis. Vegetation History and Archaeobotany, 16: 251-258. doi:10.1007/s00334006-0039-9

KomÁreK, M., EtTler, V., ChrastnÝ, V., \& MihaljeVic, M., 2008. Lead isotopes in environmental sciences: A review. Environment international, 34: 562-577. doi:10.1016/j.envint.2007.10.005

Küttner, A., Mighall, T.M., De Vleeschouwer, F., Mauquoy, D., Martínez Cortizas, A., Foster, I.D.L., \& KRUPP, E., 2014. A 3300-year atmospheric metal contamination record from Raeburn Flow raised bog, south west Scotland. Journal of Archaeological Science, 44: 1-11. doi:10.1016/ j.jas.2014.01.011
Kylander, M.E., KlAminder, J., BindleR, R., \& Weiss, D.J., 2010. Natural lead isotope variations in the atmosphere. Earth and Planetary Science Letters, 290: 44-53. doi:10.1016/j.epsl.2009.11.055

Kylander, M.E., Weiss, D.J., MartíneZ-Cortizas, A., SPIRO, B., Garcia-SANChEZ, R., \& COlES, B.J., 2005. Refining the pre-industrial atmospheric $\mathrm{Pb}$ isotope evolution curve in Europe using an 8000 year old peat core from NW Spain. Earth and Planetary Science Letters, 240: 467-485. doi:10.1016/j.epsl.2005.09.024

LEBLANC, M., 2000. 4,500-year-old minig pollution in Southwestern Spain: long-term implications for modern mining pollution. Economic Geology, 95: 655-662.

LEWIS, P.R., \& JonES, G.D.B., 1970. Roman Gold-Mining in North-West Spain. The Journal of Roman Studies, 60: 169-185.

López-Merino, L., Cortizas, A.M., López-SÁez, J.A., \& MARTÍNEZ CORTIZAS, A., 2011. Human-induced changes on wetlands: a study case from NW Iberia. Quaternary Science Reviews, 30: 2745-2754. doi:10.1016/j.quascirev.2011.06.004

LóPez-Merino, L., LóPeZ-SÁez, J. A. A., AlbA-SÁncheZ, F., PÉrEZ-DÍAZ, S., \& CARRIÓN, J.S.S., 2009 2000 years of pastoralism and fire shaping highaltitude vegetation of Sierra de Gredos in central Spain. Review of Palaeobotany and Palynology, 158: 42-51. doi:10.1016/j.revpalbo.2009.07.003

López-Merino, L., Martínez Cortizas, A., Reher, G.S., López-SÁEz, J. A., Mighall, T.M., \& Bindler, R. 2014. Reconstructing the impact of human activities in a NW Iberian Roman mining landscape for the last 2500 years. Journal of Archaeological Science, 50: 208-218. doi:10.1016/j.jas.2014.07.016

Mackenzie, A.B., Farmer, J.G., \& Sugden, C.L., 1997. Isotopic evidence of the relative retention and mobility of lead and radiocaesium in Scottish ombrotrophic peats. The Science of the Total Environment, 203: 115-127.

MACKLIN, M., 1992. Metal polluton of soils and sediments: a geographical perspective, in: Newson, M.D. (Ed.), Managing the Human Impact on the Natural Environment: Patterns and Processes. London,Belhaven Press: 172-195.

Martínez Cortizas, A., García-Rodeja, E., PonteveDra Pombal, X., Nóvoa Muñoz, J.C., Weiss, D., Cheburkin, A., \& Martinez CortizA, A., 2002a. Atmospheric $\mathrm{Pb}$ deposition in Spain during the last 4600 years recorded by two ombrotrophic peat bogs and implications for the use of peat as archive. The Science of the Total Environment, 292: 33-44.

Martínez Cortizas, A., García-Rodeja Gayoso, E., \& WEISS, D., 2002b. Peat bog archives of atmospheric metal deposition. The Science of the Total Environment, 292: 1-5.

Martínez Cortizas, A., LóPez-Merino, L., Bindler, R., Mighall, T., \& Kylander, M., 2013. Atmospheric $\mathrm{Pb}$ pollution in $\mathrm{N}$ Iberia during the late Iron Age/Roman times reconstructed using the highresolution record of La Molina mire (Asturias, Spain). Journal of Paleolimnology, 50: 71-86. doi:10.1007/s10933-013-9705-y 
Martínez Cortizas, A., Mighall, T., Pontevedra PomBal, X., Nóvoa Muñoz, J.C.C., Peiteado VareLA, E., \& Piñeiro Rebolo, R., 2005. Linking changes in atmospheric dust deposition, vegetation change and human activities in northwest Spain during the last 5300 years. The Holocene, 15: 698706. doi:10.1191/0959683605hl834rp

Martínez Cortizas, A., PonteVedra Pombal, X., NóvoA MuÑoz, J.C., \& GarCía Rodeja, E., 1997. Four thousand years of Atmospheric $\mathrm{Pb}, \mathrm{Cd}$ and $\mathrm{Zn}$ deposition recorded by the ombrotrophic peat bog of Penido Vello (Northwestern Spain). Water, Air, and Soil Pollution, 100: 387-403.

McKeown, S., 1994. The analysis of wood remains from mine 3, Mount Gabriel. In: O’Brien, W.F. (Ed.) Mount Gabriel: Bronze Age mining in Ireland. Bronze Age Studies 3. National University of Ireland, Galway: 265-280.

MEDEANIC, S., \& SiLVA, M.B., 2010. Indicative value of non -pollen palynomorphs (NPPs) and palynofacies for palaeoreconstructions: Holocene Peat, Brazil. International Journal of Coal Geology, 84: 248-257. doi:10.1016/j.coal.2010.08.015

Michelutti, N., Simonetti, A., Briner, J.P., Funder, S., Creaser, R. A, \& Wolfe, A.P., 2009. Temporal trends of pollution $\mathrm{Pb}$ and other metals in eastcentral Baffin Island inferred from lake sediment geochemistry. The Science of the Total Environment, 407: 5653-5662. doi:10.1016/j.scitotenv.2009.07.004

Mighall, T.M., Abrahams, P.W., Grattan, J.P., Hayes, D., Timberlake, S., \& Forsyth, S., 2002a. Geochemical evidence for atmospheric pollution derived from prehistoric copper mining at Copa Hill, Cwmystwyth, mid-Wales, UK. The Science of the Total Environment, 292: 69-80.

Mighall, T.M., \& Chambers, F.M., 1993. The environmental impact of prehistoric mining at Copa Hill, Cwmystwyth, Wales. The Holocene, 3: 260-264.

Mighall, T.M., \& Chambers, F.M., 1997. Early Ironworking and its Impact on the Environment: $\mathrm{Pa}$ laeoecological Evidence from Bryn y Castell Hillfort, Snowdonia, North Wales. Proceedings of the Prehistoric Society, 63: 199-219.

Mighall, T.M., Chambers, F.M., Lanting, J.M., AND O'BRIEN, W.F. 2000a. Prehistoric copper mining and its impact on vegetation: palaeoecological evidence from Mount Gabriel, Co. Cork, South-West Ireland. In: Nicholson, R.A. and O'Connor, T.P. (Eds), People as an Agent of Environmental Change. Symposia of the Association of Environmental Archaeology No. 16. Oxbow Books, Oxford: 19-29.

Mighall, T.M., Grattan, J.P., Timberlake, S., Lees, J., \& ForSYTH, S., 2002b. An atmospheric pollution history for lead-zinc mining from the Ystwyth Valley, Dyfed, mid-Wales, UK as recorded by an upland blanket peat. Geochemistry: Exploration, Environment, Analisis, 2: 175-184.

Mighall, T.M., Martinez Cortizas, A., Biester, H., \& TURNER, S.E., 2006a. Proxy climate and vegetation changes during the last five millennia in NW Iberia: Pollen and non-pollen palynomorph data from two ombrotrophic peat bogs in the North Western Iberian Peninsula. Review of Palaeobotany and Palynology, 141: 203-223. doi:10.1016/j.revpalbo.2006.03.013
Mighall, T.M., Martinez Cortizas, A., Silva SÁnchez, N., Foster, I.D.L., Singh, S., Bateman, M., \& PICKIN, J., 2014. Identifying evidence for past mining and metallurgy from a record of metal contamination preserved in an ombrotrophic mire near Leadhills, SW Scotland, UK. The Holocene. In Press. doi:10.1177/0959683614551228

Mighall, T.M., Timberlake, S., Foster, I.D.L., Krupp, E., \& SINGH, S., 2009. Ancient copper and lead pollution records from a raised bog complex in Central Wales, UK. Journal of Archaeological Science, 36:1504-1515. doi:10.1016/j.jas.2009.03.005

Mighall, T.M., Timberlake, S., Jenkins, D.A., \& Grattan, J.P., 2006b. Using bog archives to reconstruct paleopollution and vegetation change during the late Holocene. In: MARTINI, I.P., MARTíneZ, A., Chesworth, W. (Eds.), Peatlands: Evolution and Records of Environmental and Climate Changes. Amsterdam, Elsevier: 409-429. doi:10.1016/S0928-2025(06)09017-1

Mighall, T.M., Timpany, S., Critchley, M.F., Martínez Cortizas, A., \& Silva SÁnchez, N., 2013. A palaeoecological assessment of the impact of former metal mining at glendalough, County Wicklow Ireland. Mining Heritage Trust of Ireland, 13: 9-22.

Monna, F., Galop, D., Carozza, L., Tual, M., Beyrie, A., Marembert, F., Chateau, C., Dominik, J., \& GROUSSET, F.E., 2004a. Environmental impact of early Basque mining and smelting recorded in a high ash minerogenic peat deposit. The Science of the Total Environment, 327: 197-214. doi:10.1016/ j.scitotenv.2004.01.010

Monna, F., Petit, C., Guillaumet, J.-P., JouffroyBAPICOT, I., BLANCHOT, C., DOMINIK, J., LOSNO, R., Richard, H., LÉVÊQue, J., \& Chateau, C., 2004b. History and environmental impact of mining activity in Celtic Aeduan territory recorded in a peat bog. Environmental Science \& Technology, 38: 665-673.

MunKSGAARD, N.C.U., \& PARRY, D.L., 1998. Lead isotope ratios determined by ICP-MS : Monitoring of mining-derived metal particulates in atmospheric fallout , Northern Territory, Australia. The Science of the Total Environment, 217: 113-125.

Murozumi, M., Chow, T.J., \& Patterson, C., 1969. Chemical concentrations of pollutant lead aerosols, terrestrial dusts and sea salts in Greenland and Antarctic snow strata. Geochimica et Cosmochimica Acta, 33: 1247-1294.

NRIAGU, J., 1983. Lead and lead poisoning in antiquity. New York \& Chichester, John Wiley. doi:10.1016/00046981(86)90302-1

OreJAS, A., 1996. Arqueología de los paisajes mineros antiguos en la península ibérica. Brocar, 20: 7-29.

Outridge, P.M., Hermanson, M.H., Lockhart, W.L., Utridge, P.M.O., ERManson, M.H.H., \& OCKHART, W.L.L., 2002. Regional variations in atmospheric deposition and sources of anthropogenic lead in lake sediments across the Canadian Arctic. Geochimica et Cosmochimica Acta, 66: 3521-3531.

Pontevedra-Pombal, X., Mighall, T.M., NóvoAMuñoz, J.C., Peiteado-Varela, E., RodríguezRACEDO, J., García-Rodeja, E., \& MARTíneZCORTIZAS, A., 2013. Five thousand years of atmospheric $\mathrm{Ni}, \mathrm{Zn}, \mathrm{As}$, and $\mathrm{Cd}$ deposition recorded in bogs 
from NW Iberia: prehistoric and historic anthropogenic contributions. Journal of Archaeological Science, 40: 764-777. doi:10.1016/j.jas.2012.07.010

Py, V., Véron, A., Edouard, J.L., Beaulieu, J.L. De, Ancel, B., Segard, M., Durand, A., \& Leveau, P., 2014. Interdisciplinary characterisation and environmental imprints of mining and forestry in the upper Durance valley (France) during the Holocene. Quaternary International, 353: 74-97. doi:10.1016/j.quaint.2014.05.002

ReImAnN, C., \& DE CARITAT, P., 2000. Intrinsic Flaws of Element Enrichment Factors (EFs) in Environmental Geochemistry. Environmental science \& Technology, 34: 5084-5091.

RenberG, I., BränNVAll, M.-L., Bindler, R., \& EMTERYD, O., 2000. Atmospheric Lead Pollution History during Four Millennia (2000 BC to 2000 $\mathrm{AD}$ ) in Sweden. AMBIO: A Journal of the Human Environment, 29: 150-156.

RENBERG, I., BRÄNNVALl, M.-L., BINDLER, R., \& EMTERYD, O., 2002. Stable lead isotopes and lake sediments - a useful combination for the study of atmospheric lead pollution history. The Science of the Total Environment, 292: 45-54.

RIERA, S., LÓPEz SÁEZ, J.A., \& JuliÀ, R., 2006. Lake responses to historical land use changes in northern Spain: The contribution of non-pollen palynomorphs in a multiproxy study. Review of $\mathrm{Pa}$ laeobotany and Palynology, 141: 127-137. doi:10.1016/j.revpalbo.2006.03.014

Rosman, K.J.R., Chisholm, W., Boutron, C.F., CanDELONE, J.P., \& HONG, S., 1994. Isotopic evidence to account for changes in the concentration of lead in Greenland snow between 1960 and 1988. Geochimica et Cosmochimica Acta, 58: 3265-3269. doi:10.1016/0016-7037(94)90054-X

Rosman, K.J.R., Chisholm, W., Boutron, C.F., CanDELONE, J.-P., JAFFREZO, J.-L., \& DAVIDSON, C.I., 1998. Seasonal variations in the origin of lead in snow at Dye 3, Greenland. Earth and Planetary Science Letters, 160: 383-389. doi:10.1016/S0012821X(98)00098-3

SÁnchez-Palencia, F.J., SAstre, I., Currás, B., \& RoMERO, D., 2009. Minería romana en la cuenca meridional de los ríos Sil y Miño. Revista Aquae Flaviae, 41: 16-21.

SHOTYK, W., 1996. Peat bog archives of atmospheric metal deposition: geochemical evaluation of peat profiles, natural variations in metal concentrations, and metal enrichment factors. Environmetal Reviews, 4: 149-183.

SHOTYK, W., 1998. History of Atmospheric Lead Deposition Since 12,370 14C yr BP from a Peat Bog, Jura Mountains, Switzerland. Science, 281: 1635-1640. doi:10.1126/science.281.5383.1635

SHOTYK, W., 2002. The chronology of anthropogenic, atmospheric $\mathrm{Pb}$ deposition recorded by peat cores in three minerogenic peat deposits from Switzerland The Science of the Total Environment, 292: 19-31.

Shotyk, W., Cheburkin, A.K., Appleby, P.G., FAnKHAUSER, A., \& KRAMERS, J.D., 1996. Two thousand years of atmospheric arsenic, antimony, and lead deposition recorded in an ombrotrophic peat bog profile, Jura Mountains, Switzerland. Earth and Planetary Science Letters, 145:E1-E7.
ShotyK, W., Goodsite, M.E.E., Roos-Barraclough, F., Frei, R., Heinemeier, J., Asmund, G., Lohse, C., \& HANSEN, T.S.S., 2003. Anthropogenic contributions to atmospheric $\mathrm{Hg}, \mathrm{Pb}$ and $\mathrm{As}$ accumulation recorded by peat cores from southern Greenland and Denmark dated using the 14C "bomb pulse curve". Geochimica et Cosmochimica Acta, 67: 3991-4011. doi:10.1016/S0016-7037(03)00409-5

Shotyk, W., Weiss, D., Kramers, J.D., FeI, R., CheBURKIN, A.K., GloOr, M., \& Reese, S., 2001. Geochemistry of the peat bog at Etang de la Gruère , Jura Mountains , Switzerland, and its record of atmospheric $\mathrm{Pb}$ and lithogenic trace metals (Sc, Ti, Y, Zr, and REE) since 12,370 C yr BP. Geochimica et Cosmochimica Acta, 65: 2337-2360.

SILVA-SÁNCHEZ, N., 2010. Cambios ambientales en los últimos 3000 años en el sector occidental de la Sierra del Bocelo a partir de indicadores geoquímicos y palinológicos. Tesina. Tesina de Licenciatura. Universidad de Santiago de Compostela.

Silva-SÁnchez, N., Martínez Cortizas, A., \& LópezMERINO, L., 2014. Linking forest cover, soil erosion and mire hydrology to late-Holocene human activity and climate in NW Spain. The Holocene, 24: 714-725. doi:10.1177/0959683614526934

SzabÓ, P., MüllerovÁ, J., SuchánKovÁ, S., \& KotaČKA, M., 2015. Intensive woodland management in the Middle Ages: spatial modelling based on archival data. Journal of Historical Geography, 48: 1-10. doi:10.1016/j.jhg.2015.01.005

TIMBERLAKE, S. 2001 Mining and prospection for metals in Early Bronze Age Britain - making claims within the archaeological landscape. In: Bruck, J. (Ed.) Bronze Age Landscapes -Tradition and Transformation, publ. Oxbow Books, 179-192

VAN GEEL, B., 2001. Non-pollen palynomorphs. In: Smol, J.P., Birks, H.J.B., Last, W.M. (Eds.), Tracking Environmental Change Using Lake Sediments. Volume 3: Terrestrial, Algal, and Siliceous Indicators. Dordrecht, The Netherlands, Kluwer Academic Publishers:1-18.

VAn Geel, B., Coope, G.R.R., \& VAN Der Hammen, T., 1989. Palaeoecology and stratigraphy of the lateglacial type section at Usselo (the Netherlands). $R e$ view of Palaeobotany and Palynology, 60: 25-129. doi:10.1016/0034-6667(89)90072-9

Weiss, D., ShotyK, W., Appleby, P.G., Kramers, J.D., \& Cheburkin, A.K., 1999. Atmospheric Pb Deposition since the Industrial Revolution Recorded by Five Swiss Peat Profiles: Enrichment Factors, Fluxes, Isotopic Composition, and Sources. Environmental Science \& Technology, 33: 1340-1352. doi:10.1021/es980882q

Weiss, D., ShotyK, W., Boyle, E. A, Kramers, J.D., APPLEby, P.G., Cheburkin, A.K., \& Weiss, D., 2002. Comparative study of the temporal evolution of atmospheric lead deposition in Scotland and eastern Canada using blanket peat bogs. The Science of the Total Environment, 292: 7-18.

YANG, H., \& Rose, N., 2005. Trace element pollution records in some UK lake sediments, their history, influence factors and regional differences. Environment International, 31: 63-75. doi:10.1016/ j.envint.2004.06.010 